\title{
北海道恵庭市恵み野を事例とした住民の庭づくりに対 する意識と取り組みについて
}

\section{Attitude of the Residents toward Private Gardening in Megumino ,Hokkaido}

\author{
川根あづさ* 愛甲哲也* 浅川昭一郎* \\ Azusa KAWANE Tetsuya AIKOH Shoichiro ASAKAWA
}

\begin{abstract}
摘要：都市域での住宅の庭は住環境・地区環境の良否に関わり，生態的な役割や街並み景観への寄与， コミュニティ形成の媒体としての働きも期待される。本研究では, 花づくりが盛んな地域の戸建て住 宅地を対象に, 住民の庭づくりに対する意識や取り組み, 前庭の花づくりの状況を調査し, 住民間の 相違を探った。その結果, 庭づくりの動機としては植物との精神的な関わりが強く, 今後望むことと して庭や植物に対する知識があげられた。庭づくりの動機をもとに分類した集団間で自宅の庭のはた らきの認識や庭づくりの際の留意点などに相違がみられ，栽培植物や前庭での花を飾る場所，植え方 などの庭の実態にも相違がみられた。
\end{abstract}

\section{1.はじめに}

近年，住まいでのみごりづくりや花づくりへの関心が高まって いる。ここ数年のガーデニングブームは女性の参加で活性化して おり, 園芸, 庭いじりは余㗇活動の中でも上位を占める7。庭づ くりから得られる効果之して庭いじりや食物を得ることだけでは なく，日常生活の気晴らしや植物の美的な美しさから得られる喜 びといった精神面への效果もあることが知られている゙。都市域 での住宅の庭は，その居住者に恩恵を与えるだけではなく，街並 みの景観や住宅地の環境形成に果たす役割屯少なくないか。近年

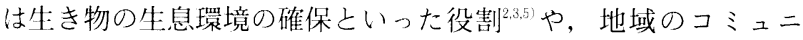
ティの形成媒体としての役割屯期待されている。

公的な役割を推進すること之私的な庭の利用はけっして矛盾す るものではないことが示されているが2)，住宅の庭は居住してい る住民の所有物であり，庭づくりを実際に行う住民の意識や取り 組みが庭のはたらきに直接影響する。庭づくり，花づくりをと拉 したまちづくりや，生き物の誘因といった公的な役割を，私的空 間である住宅の庭に求めるには，住长の庭づくりに対する意識や 取り組みに関する情報が不可欠である。

そこで，本研究では，花づくりが盛んといわれる北海道恵庭市 恵み野を事例之して，住民が庭づくりに取り組むようになったきっ かけ・動機などの庭づくりに対して抱いている意識之, 実際の世 話などの取り組み，その成果である庭の状況を調査した。さらに， 庭づくりの動機をむとに住民間の意識の相違㧍よび庭づくりにお ける取り組みとの関連を検討し，私的な空間である庭の成立に関 わる要因上公的な役割を期待する場合の留意点について考察を加 えた。

\section{2. 方法}

\section{(1) 調査地の概要}

恵み野は恵庭市の一部で札幌市の南東約 $25 \mathrm{~km}$ に位置し，札幌 圈の都市機能を分担する衛星都市を目指して開発された。調査の 対象としたのはその戸建て住宅地で, 1980 年から分譲が開始さ れた。面積は $245.7 \mathrm{ha}, 1998$ 年現在の人口は 13,119 人，4,688 世帯である。1990 年に市が開催した「花と暮らし展」を皮切り に，住民によって「恵み野花づくり愛好会」が結成され，モデル ガーデンを紹介した花マップの作成などの活動を行ってきた。そ のような取り組みが評価され，1995 年には花のまちづくりコン
クールで建設大臣賞を受賞した。噟占街主催のフラワーガーデン コンテストの実施, 図書館でのガーデニング講座など, 積極的に 市民による取り組みがなされている。市民による活動は, 全道で も注目され，他地域での花のまちづくりを触発している。マスコ ミでも紹介され，道内外から観光客が訪れている に当該地区には花づくりや庭づくりに積極的な住民が多い上予想 される。しかし，全ての住民が庭づくりに熱心なわけではない上 䓌われて抢り"，積極的に庭づくりに取り組む層から消極的な層 までが存在する地域之予想され, 住民の意識や取り組みの相違を 把握することも可能だと考えられた。

\section{（2）調查方法}

調查対象として, 分譲時期や街路の方位, 年㱓分布を考虑して 5 地区（面積 82.5ha，戸建て住宅 1,051 軒）を選定した。1998 年 11 月に各地区の $60 \%$ の家庭に配布出来るよう, アンケート用 紙を配布，直接回収した。回収できなかった世带には郵送での返 送を依頼し，数度訪問しても不在の世帯には依頼文を付け郵送で の返送を依頼した。結果として, 610 通を配有し, 443 通の有効 回答を得た（回収率 72.6\%)。アンケートは庭づくりの中心とな る人物の同答が得られるよう配慮し, 回答者は女性が約 6 割, 40 ・ 50 代がほぼ半数であった。さらに，住民の庭づくりに対する意 識が，街路に面した前庭の整備状況にどのように現れるのかをみ るため, アンケートに问答した 443 世带のうち 441 世帯に対し, 1999 年 7 月に前庭に扮ける花づくりの状況を調査した。

「庭づくりへの意識」として，アンケート調査で，庭づくりの 動機や関心，取り組みの熱心さ，住宅や庭をつくる際の景観に関 する取り決めへの意見，庭に関する困った点やマイナスの面，こ れからの庭づくりに望むこと，自宅の庭のはたらきを質問し， 「庭づくりへの取り組み」については庭の造成主体や世話時間, 除草剂の使用頻度, 使用している肥料, 庭づくりの際の留意点, 花を植える際の配慮，自分の敷地以外での除草や花植えなどの世 話の有無，友人などとの種や苗のやりとりの有無について質問し た。「実際の庭づくりの状況」については，庭全体での植物，庭 石やテーブルなど庭にある構造物, 敷地面積扔よび建坪, 塀や垣 根の有無, 高さ, 素材をアンケート調査で質問し, 境界の外側や 境界，玄関の両脇，玄関前のアプローチ，境界内非舗装部分それ ぞれでの花の有無と植え方，立体的な花の装飾の有無，壁面線後 退距離，前庭の方位を現地で調査した。この際，花の植え方は， 
地植え, プランター, ハンギングバスケットの 3 種類とした。現 地調查は, 主要な出入りが行われている力向の道路側の建物の壁 面もしくは玄関までのスペースである「前庭」を対象とした。ま た「境界」は敷地と道路間の直線上の囲障とし, それらがない場 合は敷地と道路との境界とした。

\section{3. 結果}

\section{（1）庭づくりへの意識}

庭づくりに「関心がある」人は $91 \%$ で熱心に取り組んでい る」とした人は $29 \%$ あっった。樹木や花づくり，垠の構造なよ゙ の住宅や庭を作る際の取り決めに関しては $54 \%$ 「あった方が 良い」とした。困った点やマイナスの面として,「雑草の管理に 手間がかかる」87\%，「植物の世話や手入れに手間がかかる」 68 \%などが高く認識され，これからの庭づくりに53\%が植物や庭 についての知識を望んでいた。自宅の庭のはたらきとして高く認 識されていたのは，複数回答で「栽培」89\%，「実用」76\%，「钼 賞」69\%であった。庭づくりのきっかけ・動機について，27の 項目でその強さを 5 段階で求めたところ, 「四季が感じられるこ と」や「植物や庭の美しさから得られる喜び」,「育てる喜び, 楽 しさ」,「心の安らぎ,リラックス」を $80 \%$ 以上の回答者が強く 評価していた。公的役割として期待される「街の景観の美しさへ の貢献」を強く評価した人は $43 \%$ であった。

(i ) 庭づくりの動機の因子構造

27 の動機の評価得点を用いて因子分析を行った。固有值 1 以 上で 6 因子を抽出し，その際の寄与率が $58.7 \%$ であったが，主 因子解の反復推定後の第 4 因子以下の寄与率が極めて低くなり, 固有值も 1 を下回ったため, 第 3 因子以上に限ってバリマックス 回転を行った。3 因子で累積寄与率は 48.5\%になった。因子負 荷量の高い動機の内容加, 第 1 因子から順に「精神的充足」, 「交流」，「食べ物」を表す因子であると解釈された（表一1）。

(ii）庭づくりの動機の因子得点による回答者の分類

バリマックス回転後の 3 因子の因子得点を用いて非階層的クラ スター分析を行い, 回答者の分類を試みた。 $\mathrm{R}^{2}$ 值と疑似 $\mathrm{F}$ 統計 量の変化率がほぼ安定する 4 をクラスター数とした。クラスター 間の距離は，集讨 1 と集団 2 の間が 2.11, 集闷 $1 ， 3$ 間が 2.09, 集団 1,4 間が 2.18 , 集闷 $2 ， 3$ 間が 2.14, 集讨 $2 ， 4$ 間が 1.52, 集団 $3 ， 4$ 間が 1.90 で, 集讨 1 は他集扵と最も離れていた。 分類された 4 集闷間で因子得点を比較したところ（表一 2 ）, 集闷 1 は精神的充足の動機が低く, 交流の動機, 食べ物の動機も 低い全体的に消極的な集団であった。集讨 2 は精神的充足の動機 がやや高く，交流の動機が低く，食べ物の動機が高かった。集団 3 は精神的充足の動機が高く, 交流の動機がやや高く, 食べ物の 動機が低かった。集団 4 は精神的充足, 交流の動機がやや高く, 食べ物の動機も高い，全体的に積極的な集囘であると解釈された。 各集団の人数は順に $63,87,116,167$ 人であった。動機をも之 に分類した集団間で年代, 職業, 世帯構成の違いがみられた（表一 3 ）。各集団を比較すると，集扵 1 は $20 ・ 30$ 代が $46 \% ， 60$ 代以 上が $11 \%$ と比較的若い世帯で, フルタイムの仕事に就いている 人が $41 \%$ と比較的多く, $36 \%$ が 10 歳未満の子供を持っていた。 集団 2 ではパートタイムが $26 \%$ と他集団より多く，集団 3 は専 業主婦, 無職の割合が $53 \%$ で 2 番目に多く, 集甩 4 は 60 才以上 の家族がいる世帯が $55 \%$, 専業主婦, 無職の割合が $66 \%$ と最も 多かった。

動機をもとに分類した集闷間の相違を検討するため意識に関す る設問項目とのカイ二乗検定を行ったところ，集扵間で，庭づく りへの関心, 熱心さ, 困った点やマイナスの面, これからの庭づ くりに望むこと (庭の広さ, 植物や庭についての知識), 自宅の 庭のはたらき（栽培, 観賞, 食料生産) などで意識の違いがみら
れた（表一-4）。

庭づくりに対する関心が集扵 3 , 集団 4 で特に高く（戍-1）, 庭づくりへの熱心さについても同じ傾向であった。住宅や庭をつ くる際の取り決めについては, 集団 3 はより肯定的な意見を持ち, 集団 2 は否定的であった（図-2）。集団 1 は，他集団と比較し， そのような取り決めに「関心がない」人が多かった。困った点や マイナスの面では，集甩 $3 ， 4$ は集讨 $1 ， 2$ よりも費用がかさむ

\section{表-1 庭づくりの動機の因子構造}

\begin{tabular}{|c|c|c|c|c|}
\hline \multirow[b]{2}{*}{ 項目 } & \multicolumn{3}{|c|}{ 因子負荷量 } & \multirow[t]{2}{*}{ 共通性 } \\
\hline & I & II & III & \\
\hline 生命力が感じられること & 0.74 & 0.04 & 0.17 & 0.58 \\
\hline 育てる喜び、楽しさ & 0.73 & 0.26 & 0.19 & 0.64 \\
\hline 土に触れることの楽しさ & 0.70 & 0.27 & 0.24 & 0.62 \\
\hline 四季が感じられること & 0.69 & 0.07 & 0.13 & 0.50 \\
\hline 植物や庭の美しさから得られる喜び & 0.64 & 0.30 & -0.03 & 0.50 \\
\hline 心の安らき、リラックス & 0.63 & 0.32 & -0.04 & 0.50 \\
\hline 自然に親しみ、学ふこと & 0.58 & 0.24 & 0.23 & 0.44 \\
\hline 外で過ごす気持ち良さ & 0.55 & 0.33 & 0.14 & 0.43 \\
\hline 日常生活の中の気晴らし、外レス解消 & 0.54 & 0.34 & 0.05 & 0.41 \\
\hline 出来上がったときの喜び、達成感 & 0.53 & 0.46 & 0.05 & 0.49 \\
\hline 自分の趣味の一つ & 0.51 & 0.45 & 0.07 & 0.47 \\
\hline ゆとりのある生活 & 0.50 & 0.36 & 0.00 & 0.38 \\
\hline 家族に楽しんでもらうこと & 0.46 & 0.44 & 0.08 & 0.42 \\
\hline 庭をきれいに保つこと & 0.46 & 0.38 & -0.04 & 0.36 \\
\hline 健康のため & 0.46 & 0.32 & 0.22 & 0.36 \\
\hline 庭に関した話し相手、友人の影響 & 0.22 & 0.64 & 0.03 & 0.45 \\
\hline 友人や家族と共に活動する楽しさ & 0.22 & 0.62 & 0.14 & 0.45 \\
\hline 庭作りやガーデニングの知識の增加 & 0.44 & 0.57 & 0.06 & 0.53 \\
\hline 近所の人たちとの対話や交流の場となる & 0.30 & 0.56 & 0.16 & 0.43 \\
\hline 計画をするのが楽しい & 0.37 & 0.56 & 0.06 & 0.45 \\
\hline 街の景観の美しさへの貢献 & 0.35 & 0.46 & -0.09 & 0.34 \\
\hline ひまつぶしの一つ & 0.00 & 0.34 & 0.13 & 0.13 \\
\hline 生け花やトラライフラワ-用の花を作る楽しみ & 0.32 & 0.32 & 0.21 & 0.25 \\
\hline 自分自身の食べ物を生産する楽しみ & 0.14 & 0.06 & 0.92 & 0.87 \\
\hline 無農薬栽培の食べ物を得る憘び & 0.13 & 0.08 & 0.88 & 0.81 \\
\hline 収穫の楽しさ & 0.19 & 0.04 & 0.87 & 0.79 \\
\hline 食費を浮かせること & 0.02 & 0.19 & 0.69 & 0.51 \\
\hline 寄与率 $(\%)$ & 22.29 & 14.17 & 12.04 & 48.50 \\
\hline
\end{tabular}

表ー2 動機をもとに分類した集団間の因子得点の比較

\begin{tabular}{|c|c|c|c|c|c|c|}
\hline & & 人数 & 平均値 & & F值 & \\
\hline 第 I 因子 & 集団1 & 63 & -1.410 & a & 111.6 & $\star \star \star \star$ \\
\hline \multirow[t]{3}{*}{ （精神的充足） } & 2 & 87 & 0.197 & b & & \\
\hline & 3 & 116 & 0.525 & c & & \\
\hline & 4 & 167 & 0.065 & $b$ & & \\
\hline 第II因子 & 集団1 & 63 & -0.410 & b & 113.3 & $\star \star \star \star$ \\
\hline \multirow[t]{3}{*}{ （交流） } & 2 & 87 & -0.978 & a & & \\
\hline & 3 & 116 & 0.188 & c & & \\
\hline & 4 & 167 & 0.533 & d & & \\
\hline 第而因子 & 集団1 & 63 & -0.615 & $b$ & 341.4 & $\star \star \star *$ \\
\hline \multirow[t]{3}{*}{ （食べ物） } & 2 & 87 & 0.634 & c & & \\
\hline & 3 & 116 & -1.124 & a & & \\
\hline & 4 & 167 & 0.682 & c & & \\
\hline
\end{tabular}

同一記号間には、Scheffeの多重比較検定により有意差はない $\star * * p<0.001$

表ー3 動機をもとに分類した集団と関連がみられた属性

\begin{tabular}{|c|c|c|}
\hline 項目 & & \\
\hline 年代 & 0.165 & ** \\
\hline 職業 & 0.185 & ** \\
\hline 10才未満の家族の有無 & 0.151 & * \\
\hline 60才以上の家族の有無 & 0.172 & ** \\
\hline 世帯構成 & 0.187 & \#* \\
\hline
\end{tabular}

数值はクラメールの連関係数。0〜1の範囲をとり、 0 に近づくほど 2 変数が独立であることを示す。

** $p<0.01 \quad{ }^{\star} p<0.05$ 
としていた。また, 集団1はこれからの庭づくりに対して庭の広 さや庭の知識を望まない傾向があった。自宅の庭のはたらきにつ いては（図一-3），全体に消極的な集扵 1 は自宅の庭のはたらき についての認識が「実用（駐車・物置・せんたくもの干し）「栽

表 -4 動機をもとに分類した集団と庭づくりの意識の関連

\begin{tabular}{|c|c|c|}
\hline \multicolumn{3}{|l|}{ 項目 } \\
\hline 庭づくりへの関心 & 0.285 & \#* \\
\hline 取り組みの熱心さ & 0.218 & ** \\
\hline 住宅や庭をつくる際の取り決めへの意見 & 0.139 & ** \\
\hline 困った点やマイナスの面 & & \\
\hline ・費用がかさむ & 0.182 & ** \\
\hline ・冬期の植物の置き場に困る & 0.164 & ** \\
\hline これからの庭づくりに望むこと & & \\
\hline ・庭の広さ & 0.149 & * \\
\hline ・植物や庭についての知識 & 0.259 & ** \\
\hline 自宅の庭のはたらき & & \\
\hline ・実用（駐車・物置・洗たくもの干し） & 0.071 & \\
\hline ・緩衝 & 0.143 & * \\
\hline ・プライバシーを守る & 0.092 & \\
\hline ・栽培 & 0.302 & ** \\
\hline ・いこい & 0.214 & ** \\
\hline - 観賞 & 0.308 & ** \\
\hline ·通風、日照 & 0.091 & \\
\hline • 自然との触れ合い & 0.285 & ** \\
\hline ・街の景観を美しくする & 0.254 & ** \\
\hline ・食料を生産する & 0.462 & ** \\
\hline •子供の遊び & 0.102 & \\
\hline
\end{tabular}

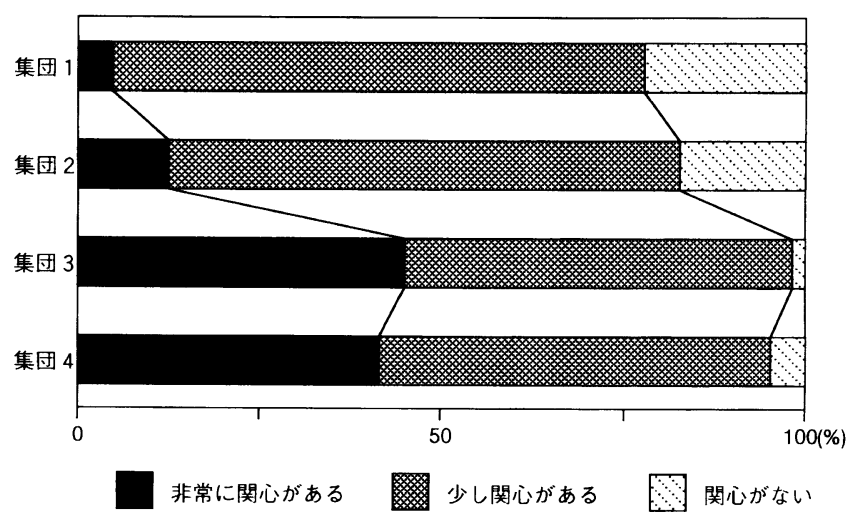

図ー1 動機をもとに分類した集団間の庭づくりへの関心

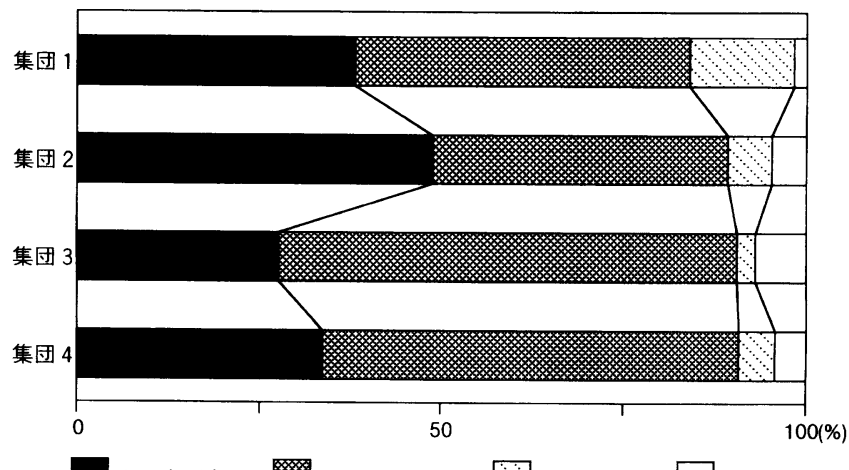

ない方が良い刓网あった方が良い 関心がない $\square$ その他

図ー2 動機をもとに分類した集団間の取り決めへの意見
培」の順に高く，それ以外は40\%以下と低かった。食べ物に積 極的な動機を持つ集讨 2 ，集闷 4 では，共に「栽培」「実用」「観 賞」の順に高く，「食料生産」が集団 $1 ， 3$ よりも高く認識され ていた。「いこい」「街の景観を美しくする」はたらきについては 集団 4 の方が集団 2 よりも高かった。精神的充足の動機が高い集 団 3 は「街の景観を美しくする」を最も認識していた。

以ト:の結果をまとめると，集扵 1 は全体的に動機が低く，庭を 観賞やいこいなどのゆとりの場としてょりも，駐車，物置など実 用的な場之して見ていた。集讨 2 と集団 4 は食べ物の栽培に関す る認識で似ているが, 集団 4 の方が庭づくりへの関心が高く, 周 囲の景観への関わりについて積極的であった。集団 3 は最む周井 の景観に対し積極的な意識を持っていた。

(2) 庭づくりへの取り組み

庭づくりの取り組みとして，週当たりの世話時間は「 $1 \sim 2$ 時 間」から「3〜4 時間」が約 6 割で,「1 時間以下」は約 2 割之 少なかった。管理の際「雑草やゴミをなくすこと」に留意してい る人が約 9 割と多かった。花を植える際に「道路側から見ても美 しいように」配慮している回答者は約 6 割で, 自分の敷地以外で の除草や花植えを約 7 割が行っていた。また, 友人や近所の人之 の種や苗のやり取りを約 8 割の回答者が行っていた。

動機をもとに分類した集忖間で庭づくりへの取り組みにも相違 がみられ，世話時間や使用している肥料, 庭づくりの際の留意点, 花を植える際の配慮などで違いがみられた（表一 5 )。集団 1 は 庭の造成を業者に委託する傾向があり，世話時間が少なく，除草

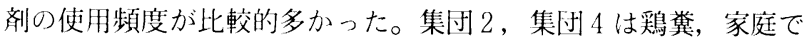
作った堆肥をより使用していた。庭づくりの際の留意点について

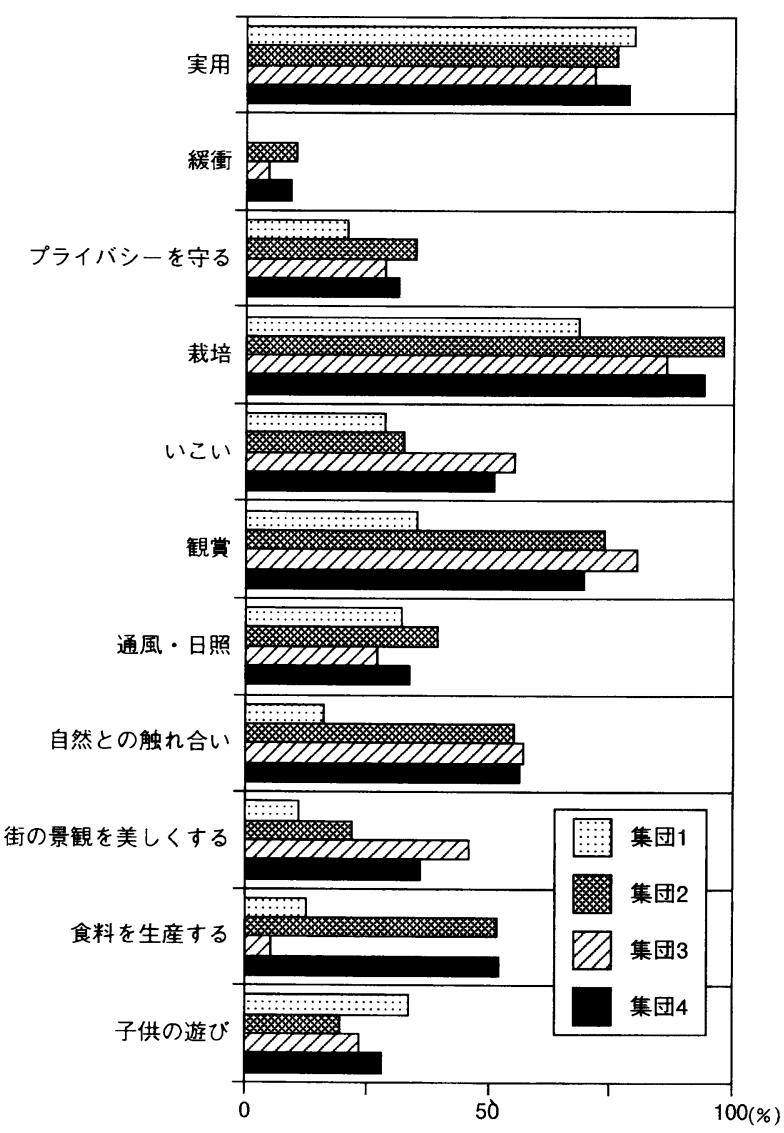

図ー3動機をもとに分類した集団間の自宅の庭のはたらきの認識 
表－5＼cjkstart動機をもとに分類した集団と庭づくりへの 取り組みの関連

\begin{tabular}{|c|c|c|}
\hline 項目 & & \\
\hline 庭の造成主体 & & \\
\hline - 家族との共同 & 0.157 & * \\
\hline ・業者 & 0.174 & $\star \star *$ \\
\hline 週当たりの世話時間 & 0.175 & $* *$ \\
\hline 除草剤の使用頗度 & 0.117 & * \\
\hline 使用している肥料 & & \\
\hline 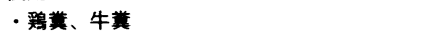 & 0.276 & $* *$ \\
\hline ·油粕 & 0.214 & ** \\
\hline - 堆肥・绿肥 & 0.218 & $* *$ \\
\hline - 家庭で作った堆肥 & 0.249 & $* *$ \\
\hline - 腐葉土 & 0.204 & $* *$ \\
\hline ・骨粉 & 0.191 & $* *$ \\
\hline - 配合肥料 & 0.151 & $*$ \\
\hline 庭づくりの際の留意点 & & \\
\hline ・雑草やゴミをなくすこと & 0.137 & * \\
\hline ・害虫が来ないようにすること & 0.171 & ** \\
\hline ・できるだけ薬剛を使わないこと & 0.236 & ** \\
\hline ・庭が使いやすいようにすること & 0.221 & $\star \star$ \\
\hline ・色のコーディネート & 0.210 & ** \\
\hline ・自然に近い形にする & 0.085 & \\
\hline 花を植える際の眍虜 & 0.188 & $\star *$ \\
\hline 自分の敷地以外での除草や花植えの有無 & 0.198 & $* *$ \\
\hline 友人や近所の人との種や苗のやりとりの有無 & 0.176 & ** \\
\hline
\end{tabular}

数值はクラメールの連関係数 ${ }^{* *} p<0.01 \quad$ * $p<0.05$

図ー4 動機をもとに分類した集団間の庭づくりの際の留意点

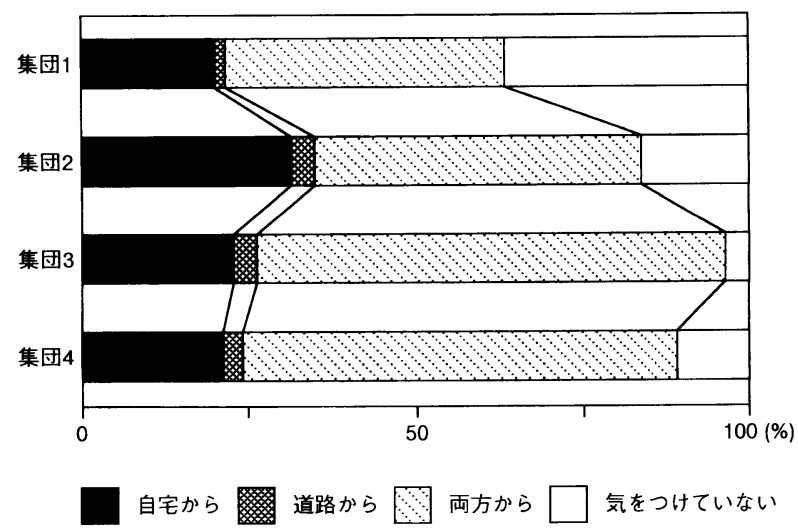

図ー5 動機をもとに分類した集団間の花を植える際の配慮

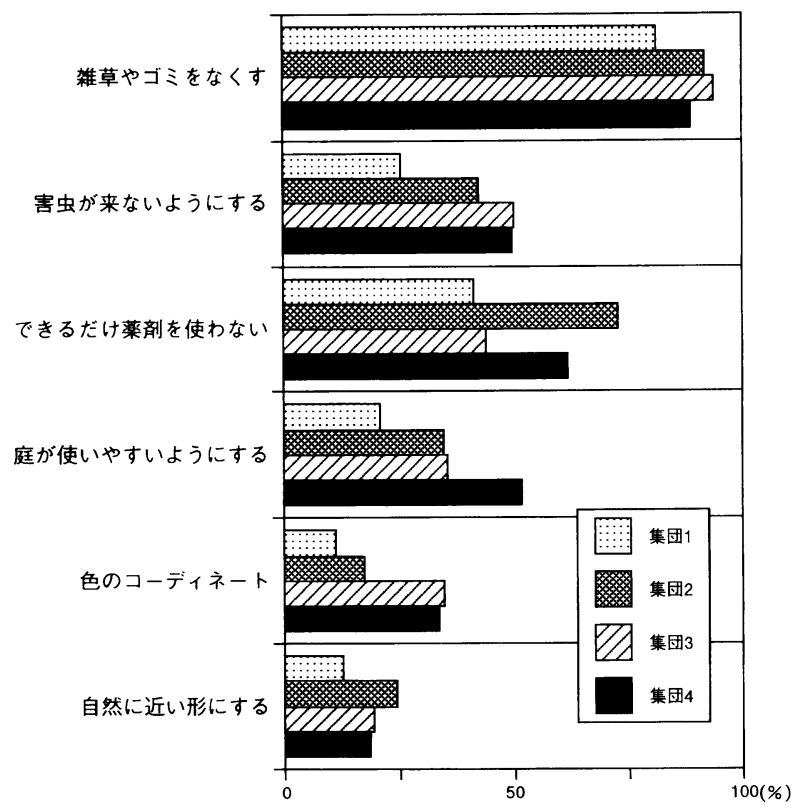

は（図-4）, 集団 1 は全般に庭づくりの際の留意点が少なく, 集団 2 ，集団 4 はできるだけ萫剂を使わないように留意し，集団 3 ，集讨 4 は色のコーディネートにより留意していた。花を植え る際の配慮として (図一-5), 集邖 2 は「自宅から見て美しいよ うに」花を植える割合がより多く，集讨 3 ，集忖 4 で「自宅と道 路両方から見て美しいように」植える割合が多かった。友人や近 所の人との種や苗のやり取りは集団 $2 \sim 4$ では 80\%以上であっ たが集讨 1 では $61 \%$ 上少なかった。

以上をま之める之，集甩 1 は庭の管理に極力手間をかけないよ うにしており，周囲之の関わりも少なかった。集闷 2 ，集闷 4 は 自然的な嘴好を持ち，集団 3 , 集団 4 で庭の見た目の美しさへの 配慮がみられた。集囘 4 は, 自然的な嗜好と庭の見た目の美しさ への配慮を併せ持つが, 集団 2 , 集団 3 ほど顕著ではなかった。 種や苗のやりとりは集団 1 のみで低く，交流への動機が低い集団 2 においても，交流の動機の高い集甩 4 上変わらずやりとりが行 われていた。これより, 庭づくりを通じた周用との関わりは，交 流の動機の有無ではなく, 庭づくりに対して何らかの動機を有し ていることによりもたらされることが示唆された。

(3) 実際の庭づくりの状況

庭全体では，低木，園芸種の花が多く栽培されていた。前庭で は，境界内非舗装部分での花づくりが $86 \%$ の家で行われており， 玄関両脇では $62 \%$ ，玄関前アプローチ $49 \%$ ，境界 $28 \%$ ，境界外 が 29\%であった。花の植え方は境界外では「地植えのみ」が 22 \%と多く，玄関両脇，玄関前アプローチでは「プランターのみ」 がそれぞれ 56\%，30\%であった。境界内非舗装部分では「地植 えのみ」の $57 \%$ に続き「地植え抢よびプランター」が24\%と多かっ た。ハンギングバスケットの使用は全体において少なく，いずれ の部分でも5\%を超えるこ上はなかった。立体的な花の装飾を行っ

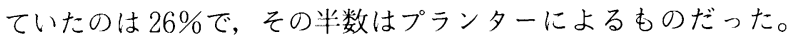
前庭のどこにも花がなかった家は $6 \%$ と少なく, 調査したほ上ん ごの家庭で何らかの花づくりがされていることが明らかになった。 動機をもとに分類した集団間で庭全体の状況，前庭での花づく りの状況にも違いがみられた（表一 6 )。庭全体では低木, 野草, 芝生を除く植物およびフェンス・トレリス，テーブル・ベンチの 有無で相違がみられ，前庭では境界部分を除く 4 簓所での花の有 無および立体的な花の装飾に違いがみられた。集団間の庭全体の 植物を図一6に示す。集讨 1 では他集団之比較し, 樹木や観葉植

\section{表－6＼cjkstart動機をもとに分類した集団と庭の状況の関連}

\begin{tabular}{|c|c|c|}
\hline $\begin{array}{l}\text { 項目 } \\
\end{array}$ & & \\
\hline \multicolumn{3}{|l|}{ 庭全体での植物 } \\
\hline ·樹木 & 0.152 & * \\
\hline ·低木 & 0.118 & \\
\hline • 果樹 & 0.184 & $\star \star$ \\
\hline ・花（園芸種） & 0.144 & * \\
\hline ·野草 & 0.133 & \\
\hline - 観葉植物 & 0.187 & $\star \star$ \\
\hline ・ハーブ & 0.149 & * \\
\hline ·野菜 & 0.597 & $\star \star$ \\
\hline · 芝生 & 0.065 & \\
\hline - 雑草 & 0.179 & ** \\
\hline \multicolumn{3}{|l|}{ 庭にある構造物 } \\
\hline ・フェンス・トレリス & 0.175 & $* *$ \\
\hline ・テーブル・ベンチ & 0.163 & $\star \star \star$ \\
\hline \multicolumn{3}{|l|}{ 前庭での花つくくりの状況 } \\
\hline - 境界外の花 & 0.164 & $\star \star \star$ \\
\hline ・境界の花 & 0.132 & \\
\hline •玄関両脇の花 & 0.225 & $\star \star *$ \\
\hline ・玄関前アプローチの花 & 0.178 & $\star \star$ \\
\hline - 境界内非舗装部分の花 & 0.205 & $\star \star$ \\
\hline •立体的な花 & 0.205 & * \\
\hline • 全体の花 & 0.195 & $\star \star$ \\
\hline
\end{tabular}


物，野菜などの植物がない傾向があった。集団 3 と 4 の相違点は 集甩 4 でより園芸品種の花，果樹，野菜があることである。集讨 2 之集讨 4 は集讨 $1 ， 3$ 之比較し, 果樹, 野菜, 園芸品種の花を 答える人が多かったが，集団 2 では雑草のある割合も高かった。 また，庭にある構造物としては，集网 $3 ， 4$ でよりテーブル・ベ ンチを庭に置き，フェンス・トレリスを集讨 3 でより置く傾向か あった。

次に前庭での花づくりの状況の相違を図ー7に示す。玄関画脇, 玄関前アプローチ，境界内非舗装部分に集団 3 でより花があり， 他集団よりも立体的な花の飾り方をする傾向があった。集団 1 は いずれの部分についても他集扵よりも花づくりをしない傾向にあ り，立体的な花の装飾もしない人が多かった。集団 $2 ， 4$ はその 中間で, 集団 2 と集甩 4 の間には前庭での花づくりの状況におけ る違いがみられなかった。

まとめると，集时 1 では庭全体の植物の有無，前庭での花づく りいずれにおいても他集団よりも比率が低く，動機の消極性が実 際の庭の状況として現れていた。集団 $2 ， 4$ は庭全体で園芸品種 の花をつくる傾向があったが，前庭部分に抢いては集时 3 でより 花を植えていることから，集囘３の街並み景観に対する積極的な 意識が前庭での花の植え方, 飾り方に現れているといえる。集団 2 は，他集讨よりも花を植える際に「自宅からみて美しいように 植える倾向があったが，前庭各所の花の植え方に拀いて集囘 4 之 の間で顕著な違いが現れなかった。この理由として，前庭の花の 配置には「自宅から」とか「道路から」という意識が影響しない 可能性，集甩 4 の「道路から」が，住民が思っているように，花 の植え方や飾り方に現れていないこと，また本研究では触れなかっ

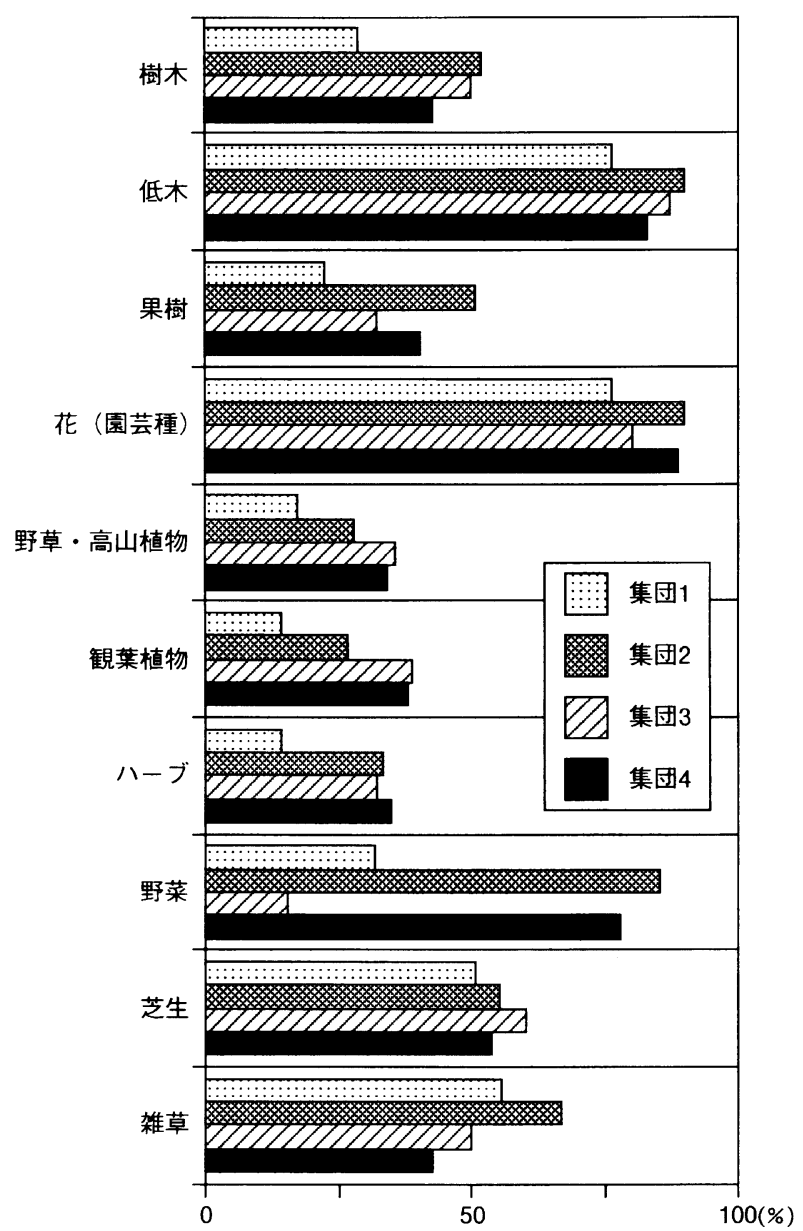

図ー6 動機をもとに分類した集団間の庭全体での植物
た，花の量や色，メンテナンスにその違いが現れている可能性が 考えられる。

\section{4. 考察}

全体として庭づくりへの高い関心が示され，花を植える際に道 路側から見た美しさにも配慮している回答者が多く，実際にほ上 んぞの回答者が前庭での花づくりを行い，花のまちと呼ばれる実 態を裏付ける結果が得られた。植物や庭についての知識を望む回 答者が多かったことから，庭づくりに積極的に取り組もうとする 住民の意識が推察された。一方, 自宅の庭のはたらきという点で, 「街の景観を美しくする」という項月は十分には認識されていな かった。その理由としては, 道路から見ても美しいように花を植 えることや前庭での花づくりが住民の考える街の景観美化にまで は到達していない可能性:, 住宅の庭づくりが街の景観の向上につ ながるという概念が浸透していないことなどが考えられる。庭づ くりの動機としては，「精神的充足」「交流」「食べ物」の 3 つの 因子があることがわかり，それらの動機の積極性㧍よび相違によ り, 庭づくりに対する意識, 取り組み, 前庭での花づくりが異な ることが明らかになった。集団毎の動機が意識抢よび取り組み, 実際の庭づくりの状況に及ぼす影響について以下に述べ，今後の まちづくりについての課題を考える。

集団 1 は, クラスター分析において他の集闷との距離が遠く, 庭づくりへの意識, 世話時間などの取り組み, 前庭での花づくり

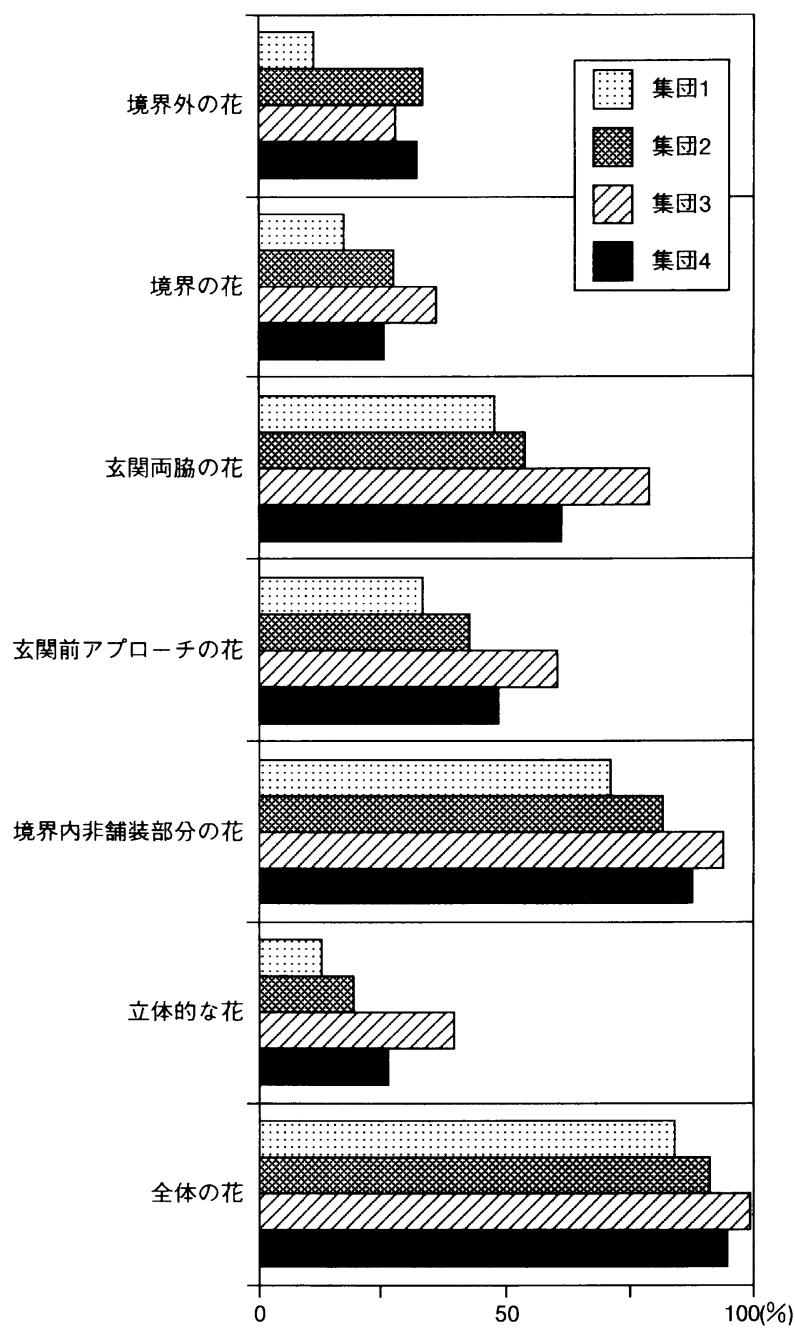

図ー7動機をもとに分類した集団間の前庭の花づくり状況 
についても全般に消極的で，顕著に他集団と異なっていた。他の 3 集団は, 精神的充足, 父流, 食へ物のうち少なくとも 1 つ以上 を動機として高く持っており, 庭づくりに対し何らかの積極性を 持っていたのに対し，集村 1 はいずれに対しても消極的であった。 これより庭づくりに最も影響を及ぼす要因が動機の種類よりもむ しろ庭づくりに対する積極性であると考えられた。この集闷には, フルタイムの仕事に就いている人が多く，10才未満の子供を持 つ世帯が多いことから庭づくりにかける時間的余裕がないことが 推察され, 庭の広さを望まず, 庭の管理に時間や手間を極力かけ ない態度がそれを裏付けている。種や苗のやりとりの少なさ, 自 宅の庭に対する実用性以外のはたらきの認識の薄さは, 庭づくり による副次的な効果む得られていないことを示している。この集 団の障害となっている「時間のなさ」を克服できるような施策, 例えば行政や住民間でのメンテナンスの一時的な負担やスプリン クラーの普及, 手間をかけずに美しさを保てる庭づくりの方法, 情報提供の方法なよ゙が今後課題となるだろう。

交流の動機が低く, 精神的充足・食べ物の動機が高い集忖 2 は 住宅や庭をつくる際の取り決めに対し否定的で, 花を植える際に 「自宅から見て美しいように」配慮していることから, 主に自分 のために庭づくりを行っているといえる。樹木, 果樹, 野菜, 雑 草が多く, 薬剤の不使用, 家庭で作った堆肥を使用することなど から庭の美しさよりもむしろ自然性, 健康を重視する集団之も考 えられる。交流に対する動機が低いにもかかわらず, 交流に積極 的な集时之同様に種や苗のやりとりが行われており，庭を介した コミュニケーションが無意識的に存在していることを何わせる。 街の景観に資する庭の役割に対しては消極的にもかかわらず前庭 各部分での花づくりが行われており, 無意識的に街の景観に貢献 していると考えられ，この効果を認識することで，この集団の庭 づくりは変化する可能性がある。現在恵み野で行われているフラ ワーガーデンコンテストは, そういった意味で効果的であると考 えられる。

食べ物の動機が低く, 精神的充足, 交流の動機の高い集団 3 で は自宅の庭のはたらきとして街の景観の美しさへの貢献という意 識がより高く, 住宅や庭に関する取り決めに肯定的であった。庭 づくりに際しては色のコーディネートに注意し, 花を植える際に 自宅からだけでなく道路側から見た美しさにも配慮する傾向があっ た。そのような意識や取り組みは前庭の各部分での花づくりや立
体的に花を飾るという行為として現れていた。この集时は花のま ちづくりを進める上で情報提供者や住民を引っ張っていくリーダー としての役割を持ちうると考えられる。

精神的充足, 交流, 食べ物全ての動機の高い集时 4 は, 色のコー ディネート，花を植える際の配虑など街の景観に対する積極性が 集団 3 に次いで高く，庭にある植物は樹木，果樹，野菜などと， 前庭での花づくりも集団 2 と差がみられなかった。美しさと食べ 物の雨方を求めて庭づくりをしている層であることがうかがわれ る。一方動機の高さが取り組みにはあまり現れておず，庭の知識 をより望んでいることから, 知識の不足がこの集村の取り組みを 阻害している可能性がある。花をより美しく見せるコッなよ゙，今 後の情報提供のあり方により，この集団の今後の花のまちづくり への貢献が期待できる。

回答者全体として街の景観の美しさに対する動機があまり高く なかったこよは、ニュージーランドのクライストチャーチの住民 がガーデニングの動機としてリラックスや植物への興味よりも街 の景観美化を高くあげている という報告と対照的である。だが 恵み野にはクライストチャーチ市にみられるような都市計曲条例 としての私有地緑化の規制はなく，それにもかかわらず街の景観 に対して積極的に取り組む集扵が存代することが本研究により明 らかになった。動機の相違により, 取り組みや庭の植物が異なっ ていたことから，花のまちづくりを進める上では，住民の嘴好性 を尊重することが重要であると考えられる。また，ライフステー ジの中で，時間の不足なよ゙により庭づくりに熱心になれない時期 があることへの理解と，それをサポートするような施策も必要で あろう。庭づくりを通じたコミュニティの無意識的な存在は, 一 斬の家が花づくりをすると，周网に伝染していくといった例りに みられるように, 強制的でないゆるやかな花のまちづくりを助け るものとして期待できる。

今回の分析では，住民の意識と現時点での取り組みに重点をお いたが，庭の広さや方位，外構の状況など空間面上の関連につい ても，さらに分析を進めたい。また，今後の課題としては住民の 取り組みの違いが植栽の量的, 質的な面によ゙のように現れるか, またよ゙のような花づくり，庭づくりが街並み景観の向上につなが るのか，花づくり，庭づくりを通じてコミュニティが形成される のか，等について検討が必要である。

\section{引用文献}

1) 北海道市長会編 (1998): 第 23 回北海 道都市問題会議（記録）：北海道书長 会, 札幌市, $109 \mathrm{pp}$

2）上甫木昭春 (1998)：居住環境形成に 資する戸建て住宅地の庭空間の公的役 割に関する研究：ランドスケープ研究 61(5), 793-796

3）上甫木昭春 (1999)：新市街地の戸建
て住宅地に打ける庭空間への生き物誘 因の実態之緑地環境形成之の関連性: ランドスケープ研究 62(5), 643-646

4 ) Kaplan, R. (1973) : Some Psychological Benefits of Gardening: Environment and Behavior 5(2), $145-162$

5 ) 中尾昌宏・服部保(1999)：三田市フラ ワータゥンに扮けるテ建て住宅庭園の
庭園植物の特色：ランドスケープ研究 $62(5), 617-620$

6 ）杉尾邦江 (1998)：ニュージーランド・ クライストチャーチに於ける私有地緑 化（ホームガーデン）の実態（その1）: PREC STUDY REPORT 2,62-69

7 ) (財) 余暇開発センター編 (1999)：レ ジャ一白書 ' 99 : 余㗇開発センター, 東京都, $145 \mathrm{pp}$

Summary: In urban areas, private gardens' vegetation contributes to neighborhood environmental quality. Recently, People have expected increased wildlife habitat, improved streetscape, and others tool of community development. To consider these roles, it is important to investigate attitudes of residents regarding their gardens in Megumino, Hokkaido. In order to understand residential perception and management, we carried out a questionnaire survey concerning vegetated flowers in front yards. The results are as follows. The strongest motivation of gardening is the act of planting. Other motivation factors include nonspecified, food production, and increase of family or neighborhood interaction. People wanted more knowledge about plants or gardening. The type of motive about gardening has influenced residents' perceptions, management, vegetation, and front yard flower arrangements. 